\title{
The water budget of an amazonian rain forest
}

Carl F. Jordan (")

Jochen Heuveidop ( ${ }^{(p)}$ )

\begin{abstract}
In a tropical rain forest near San Carlos de Rio Negro, Venezuela, average yearly precipitation from September 1, 1975, through August 31, 1977 was $3664 \mathrm{~mm}$. Throughfall was $87 \%$ of precipitation, stem flow was $8 \%$, transpiration was $47 \%$, evaporation from leaf surfaces was $5 \%$, and sub-surface runoff was $48 \%$. These results conform closely to the prediction of Marques et al. (1977) that $48 \%$ of the precipitation that falls on the central Amazon Basin is derived from evapotranspiration within the Basin.
\end{abstract}

\section{INTRODUCTION}

There has recently been an increasing interest in the water budget of forest of the Amazon Basin, due to the possibility that the water cycle may be changed due to large scale forest destruction (Marques et al. 1977; Villa Nova et al. 1976). As part of an ecosystem study in the upper Rio Negro region of the Amazon Basin (Medina et al. 1977; Herrera et al. 1978) we have been quantifying the water budget. Parts of this water budget have been published (Heuveldop 1979; Jordan \& Kline 1977; Jordan et al. 1979), but the entire budget has never been brought together in one report. Because of the importance of cuantifying input parameters to models of water flux in the Amazon region, we review here the already published data and present some unpublished data on the water budget of the tropical rain forest ecosystem at San Carlos de Rio Negro, Territorio Federal Amazonas, Venezuela, from 1 September 1975 through 31 August 1977.

\section{SITE DESCRIPTION}

The study site is located near the confluence of the Casiquiare and the Rio Guainia, which forms the Rio Negro $\left(1^{\circ} 56 \mathrm{~N}, 67^{\circ} 03 \mathrm{~W}\right)$.
Elevation is 119 meters. Dominant geologic material is the precambrian formation of the Guiana shield. The terrain is gently rolling. There are terra firme areas on well drained oxisols. Between the small hills of terra firme are areas of spodosols supporting vegetation similar to what is called Amazon caatinga or campina near Manus (Klinge et al. 1977). The studies reported here were carried out primarily on a terra firme site, approximately $4 \mathrm{~km}$ east of San Carlos.

The average yearly precipitation is 3565 $\mathrm{mm}$, but significant yearly variations occur (Fig. 1). There is no distinct dry season, in that on the average no month receives less than $200 \mathrm{~mm}$ of rain, but the months from September throughout March receive less than the average monthly precipitation, while April through August receive more (Heuveldop, in prep.).

\section{METHODS AND RESULTS}

\section{RAINFALL}

Rainfall was collected with a funnel mounted above the canopy of the forest. The water was led down through a $3 \mathrm{~cm}$ wide plastic tube to a standard Lambrecht rainfall recorder. Results on a monthly basis for September 1975 through August 1977 have been presented by Heuveldop (1979) and are reproduced here in Fig. 2. Average precipitation per year for the two-year period was $3664 \mathrm{~mm}$, a value close to the long term average of $3565 \mathrm{~mm}$ measured at the meteorology station at San Carlos. At the forest site, the mean monthly precipitation over the two-year period was $305 \mathrm{~mm}$ with a standard deviation of \pm 140 , while at the mete

(") - Institute of Ecology. University of Georgia Athens, Georgia, U.S.A.

(*) - Federal Research Centre for Forestry and Forest Products. Hamburg-Reinbek, Federal Republic of German)' Institute for World Forestry. 
orology station at San Carlos. The monthly average for the period was $300 \mathrm{~mm}$, with a standard deviation of \pm 136 .

\section{THROUGHFALL}

Throughfall was collected in four, 6-meter long, cut open PVC tubes which provided a collecting area of $3.5 \mathrm{~m}^{2}$. The water flowed down the slightly inclined tubes into a drum with 250 liters capacity, and water level was measured with an OTT water level recorder. In addition, throughfall was collected at the forest floor in 20 open-top tins in order to obtain variation coefficients.

The percent interception by the canopy varied depending upon the total amount of rainfall in the storm (Heuveldop 1979). For rains less than $5 \mathrm{~mm}, 100$ percent of the rainfall was intercepted, while for storms greater than $50 \mathrm{~mm}$, only about 8 percent was intercepted. Over the two-year period, average throughfall was 87 percent of rainfall. The amount of stemflow is not considered in this value. Near Manaus, Brazil, in a similar forest type, Nortcliff \& Thornes (1978) found an average of 74.7 percent of rainfall moved through the canopy as throughfall over a period from late March to late May 1977.

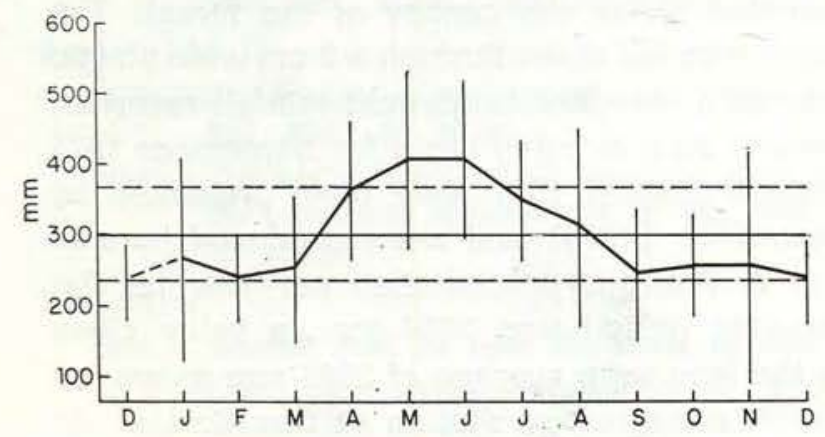

Fig. 1 - Average monthly rainfall and standard deviation at the meteorology station for San Carlos de Rio Negro, Venezuela. Data is based on observations between 1950-1958 and 1970-1978. Figure is from Heuveldop (Ms. in prep.).

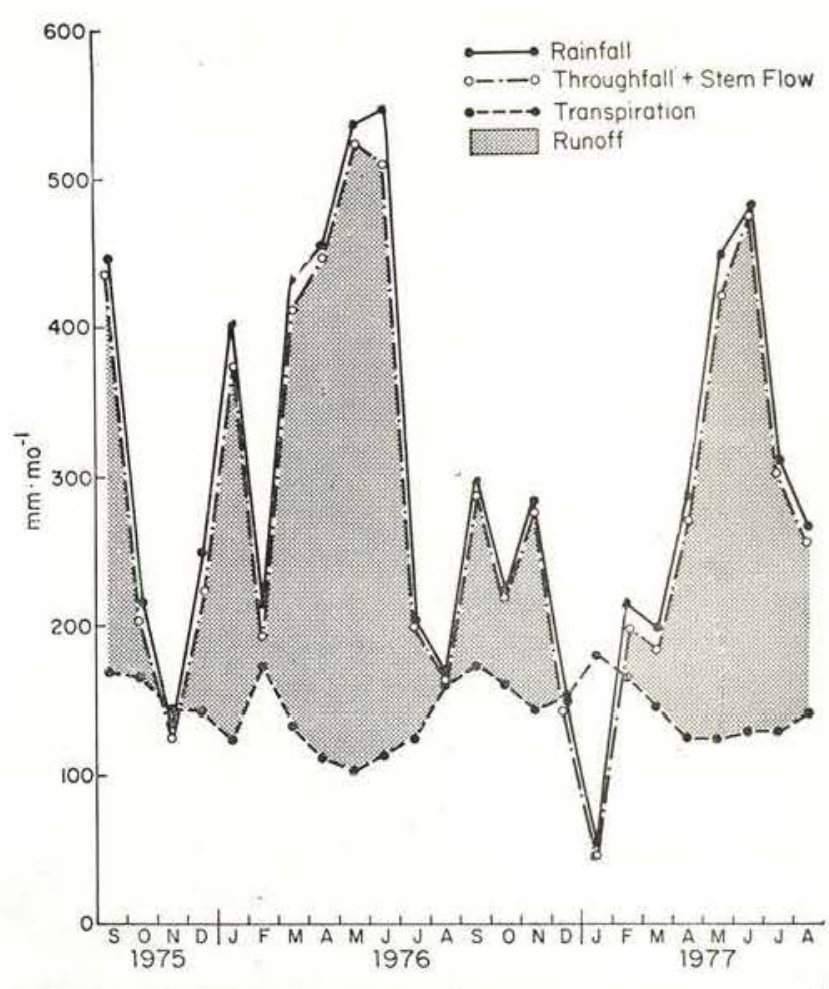

Fig. 2 - Rainfall, throughfall, stemflow, transpiration, and runoff at the field site $4 \mathrm{~km}$ east of San Carlos de Rio Negro for the period September 1, 1975 through August 31, 1977. Runoff is the difference between throughfall plus stemflow and transpiration.

Throughfall values for a site are variable, because they depend on the total amount of rainfall in a storm, rainfall intensity, (i.e., amount of rain per time unit), and frequency of rainfall events. These factors may have equal effects, become contradictory, or balance. For example, at San Carlos in July and August one often encounters rainfalls that may be intermittent for one or more days, but total amount of rain and the intensity is less compared to that which falls during a storm in January. More evaporation occurs from the leaves during the lighter rains and, therefore, throughfall is less.

\section{STEM FLOW}

Stem flow was measured on 38 trees fitted with polyurethane collars (Likens \& Eaton 1970). Water was conducted from the collars into collection barrels through plastic tubing. 
Water in the barrels was measured weekly or after major storms for one year (Jordan 1978). Stem flow per tree per year was regressed on diameter of the tree. Total stem flow per hectare per year was calculated by multiplying stem flow per size class of tree times the number of trees in each size class per hectare (Jordan \& Uhl 1978).

Stem flow averaged eight percent of precipitation (Jordan 1978). This value is higher than other reports of stem flow. We attribute this high value to the large number of small trees at the study site. Although individual trees less than $10 \mathrm{~cm}$ diameter had relatively little stem flow, there were 10469 of these trees per hectare, compared with 748 trees greater than $10 \mathrm{~cm}$, and these smaller trees contributed 89 percent of the total stem flow.

Much of the stem flow attributed to the small trees was undoubtedly first throughfall from the larger trees but probably was not collected by the throughfall collectors, since often there were branches and leaves of the small trees extending above the throughfall collectors.

\section{EVAPORATION FROM LEAF SURFACES}

Addition of the value of 8 percent of precipitation which becomes stem flow and 87 percent which becomes throughfall for the two-year period gives a total of 95 percent of the precipitation, or $3480 \mathrm{~mm}$ per year which reached the the forest floor. The difference between this figure and average yearly rainfall for the two-year period must be equal to the evaporation from leaf surfaces. Since rainfall averaged $3664 \mathrm{~mm}$, evaporation from leaf surfaces must have been $184 \mathrm{~mm}$ or five percent of precipitation.

\section{TRANSPIRATION}

Transpiration of the forest was measured by the tritium method (Kline et al. 1976). A series of trees is injected with tritiated water and the rate at which the tritium is diluted is determined by water samples taken from the twigs. Dilution rate is directly proportional to the transpipration rate of the trees. Jordan \& Kline (1977) have shown that at the San Carlos site, transpiration is independent of species and is directly proportional to the sapwood area of the trees. By estimating the sapwood area of the forest and by measuring transpiration over 13 intervals in trees with a known sapwood area, Jordan et al. (1979) were able to compute the transpiration of the forest.

During most of the year, the transpiration rate determined by the tritium method was not different from the calculated potential transpiration determined by a Class $\mathrm{A}$ evaporation pan and corrected for interception losses at the forest site (Jordan et al. 1979). However, occasionally the tritium method gave results slightly higher than those predicted by the evaporation pan, especially during periods when there was a high percentage of direct sunlight. We suspect that this effect may be caused by an a!bedo at the study site which is slightly lower than that for surrounding areas.

Transpiration calculated by the tritium method was $2186 \mathrm{~mm}$ per year, by the Pan A corrected for interception losses it was 1720 $\mathrm{mm}$ per year, and by the energy budget it was $1627 \mathrm{~mm}$ per year (Jordan et al. 1979). For the transpiration values plotted in Fig. 2, we have used the Pan A values, since the tritium method may have overestimated transpiration during several months, and the energy budget method contained an unconfirmed assumption about the cllbedo at the site.

\section{EVAPORATION FROM FOREST FLOOR}

A gravimetric study on evaporation of water from the forest floor was carried out, but in contrast to the other portions of the water budget, the data have not been presented elsewhere. Therefore, a complete description of methods and presentation of results are given here.

A series of beer cans were used as containers for soil in order to determine weight loss Tops were removed from beer cans, and a small hole was punched in the bottom of the cans to permit drainage of free water. Cans were partially filled with inorganic soil material 
from the site in which the measurements were to be taken. Then a cylinder of organic surface material was cut with a diameter equal to that of the can, and inserted on top of the inorganic soil inside the cans to simulate the natural soil cover. Holes were dug in the measurement sites with a bucket auger that had a diameter equal to that of the cans. Holes were of such a depth that the top of the cans would be flush with the soil surface. Early in the morning, cans were weighed to the nearest tenth of a gram in the field laboratory, then covered and transported to the field sites, where they were inserted in the holes. They were left during the entire day, removed and immediately covered in the late afternoon, and brought to the laboratory where they were immediately weighed again. On days when there was rain during the day, the experiment was abandoned.

Evaporation from the forest floor was very small (Table 1). The greatest value was $.4 \mathrm{~mm}$, and there were several days during which no measurable evaporation occurred. Average evaporation was $.1 \mathrm{~mm}$ per day, or $3 \mathrm{~mm}$ per month. These observations were carried out in September and November 1977 which both were relatively dry months, with $198 \mathrm{~mm}$ and $141 \mathrm{~mm}$ of rainfall respectively. For wetter months with shorter periods between rainfail events, we may assume evaporation to be even less. Since $3 \mathrm{~mm}$ or less per month of evapu. ration from the soil is negligible compared to the rest of the water budget presented in Fig. 1 , it is not included.

Total evapotranspiration per year for the two-year period then is $1720 \mathrm{~mm}$ transpiration by the Pan A method plus $184 \mathrm{~mm}$ of evaporation from leaf surfaces. The total, $1904 \mathrm{~mm}$, is 52 percent of precipitation.

\section{RUNOFF}

Runoff here is defined as the water leaving the root zone and percolating downward and laterally to drainage streams. We have not measured runoff directly, but calculated it as the difference between the water entering the soil (throughfall plus stem flow) and the Water leaving the soil by evapotranspiration. Since evaporation from the forest floor is very low, we have taken evapotranspiration of soil water to be essentially equal to transpiration from the leaves. Evaporation from the leaf surfaces has already been taken into account in our calculations as the difference between rainfall and throughfall. Runoff is shown as the shaded area between throughfall plus stem flow and transpiration in Fig. 2. Average runoff per year was $1760 \mathrm{~mm}$ over the two-year period.

There are two months shown in Fig 1 where runoff is indicated as negative. This is an impossibility of course. It is a result of

TABLE 1 - Evaporation from soil cans at two sites in the undisturbed forest. All dates are 1977.

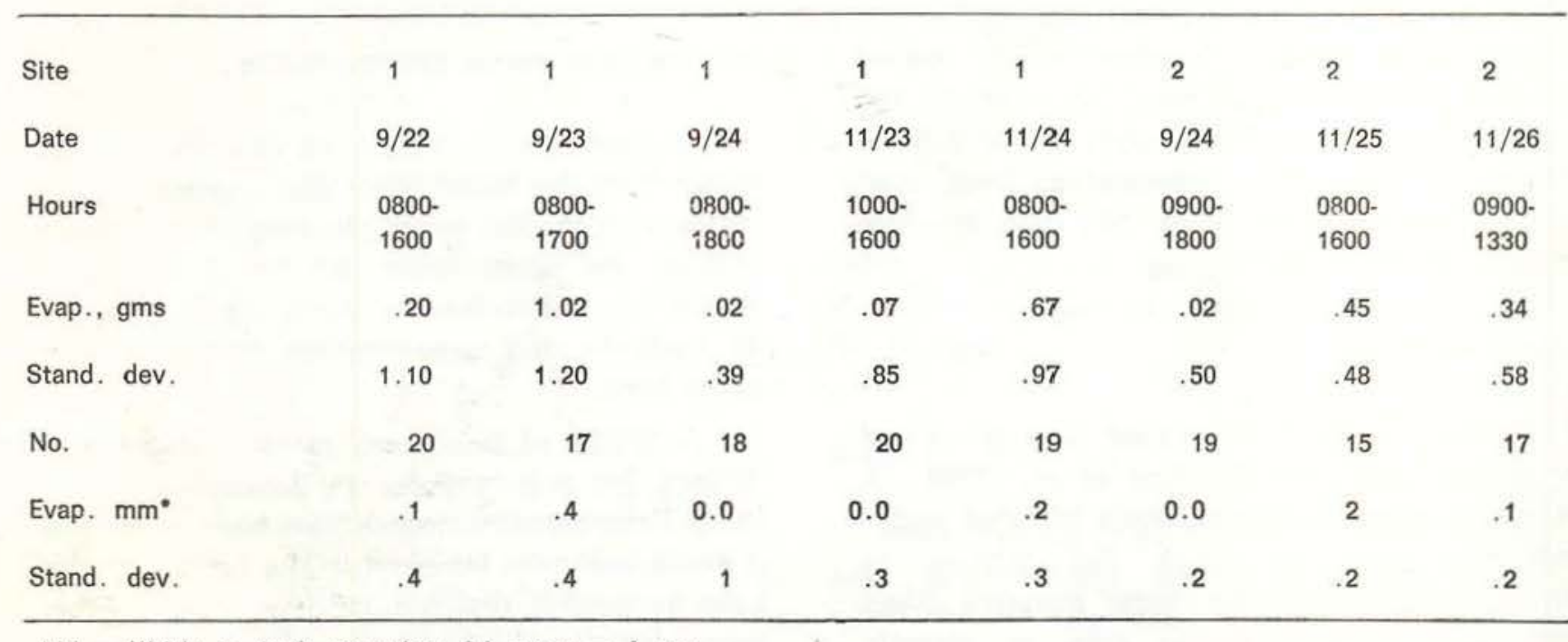

(*) - Weight to depth conversion: 3.1 grams $=1 \mathrm{~mm}$. 
the assumption implied in Fig. 2 that all the water that enters the soil during a given month runs oft during that month. A large portion of the water from each rainstorm percolates to nearby streams very rapidly, but there is another fraction retained at high tensions in the lower soil horizons which drains very slowly (Nortcliff and Thornes 1978). The result is that during some months runoff is not actually the difference between input and transpiration as shown in Fig. 1 but is somewhat less and this temporary storage makes up the difference between transpiration and in input during months such as January 1977.

Herrera (1979) has calculated runoff in the drainage basin of the upper Rio Negro by dividing the total stream flow at San Carlos as measured at the hydrologic station there by the area of the catchment basin. His calculation yield's an average value of $1564 \mathrm{~mm}$ per year. Differences between Herrera's value and our value can easily be accounted for by differences in year-to-year and point-to-point precipitation.

\section{DISCUSSION}

Marques et al. (1977) have calculated that 48 percent of the precipitation which falls in the eastern and central Amazon Basin is derived from evapotranspiration within the Basin. This is quite remarkable in that for most of the other regions of the world, only about 12 percent of the precipitation is derived from local evapotranspiration (Budyko 1974). The high percentage of locally derived water from precipitation in the Amazon Basin indicates that careful consideration should be given to possible consequences such as desertification resulting from destruction of large areas of forest, since forests are more efficient at returning water to the air than are crop plants. savannah vegetation, or bare soil.

The results of the study presented here indicate that the modiel of Marques et al. (1977) is valid also for the upper Rio Negro region of the Amazon Basin. They predict that 48 of 100 water molecules in a cloud above the Amazon Basin come from within the Basin, and
52 come from outside. For San Carlos we predict that 47 of 100 molecules which fall as precipitation will be transpired and 5 will be evaporated for a total of 52 molecules locally recycled. The remaining 48 molecules will flow down the Rio Negro to the Amazon and then to the Atlantic to be eventually evaporated on the way downstream and from the sea.

The calculated four percent difference between our estimate of regional recycling of water and that of Marques et al. (1977) could be a result of regionai or temporal variations, or it could be a result of inaccuracies in the measurements leading to either or both of the predictions .

\section{ACKNOWLEDGEMENT}

This study was part of the San Carlos project which receives support from the U.S. National Science Fcundation, OAS, UNESCO through their MAB 1 program, the Deutsche Forschungsgemeinschaft, and CONICIT de Venezuela. The project is headquartered at Centro de Ecologia, Instituto Venezolano de Investigaciones Cientificas, Caracas, Venezuela. We thank Drs. Ernesto Medina and Rafael Herrera for their assistance and advice throughout the study.

\section{Resumo}

Foram feitas medições de econnmia de água numa floresta tropical úmida perto de San Cários de Rio Negro (Venezuela), no período de 1.9.1975 a 31.8.1977. as quais causaram: Precipitação média anual - 3,604mm; água de lavagem das folhas $-87 \%$ de precipitação: água de escorrimento dos troncos $-8 \%$; transpiração - $47 \%$; evaçoração das folhas $-5 \%$; e o fluxo subsuperficial - $48 \%$.

Esses dados concordam com os de Marques et al. (1977) que afirmaram que $48 \%$ da brecipitaçẽo na Amazônia Central é derivada da exapotranspiração dentro da bacia.

\section{REFERENCES}

BUDYKo, M.I.

1974 - Climate and Life. English edition. published by Academic Press, New York.

HerrerA, R.

1979 - Nutrient distribution and cycling in an Amazon caatinga forest on spodsols in southern Venezuela. Ph.D. Thesis. Univ. of Reading, Reading, Englond. 
Herrera, R.; Jordan, C.F.; Klinge H.; Medina, E. 1978 - Amaon ecsystems. Their structure and functioning with particular emphasis on nutrients. Interciencia, 3, 223-232.

HEUVELDOP, J.

1979 - The international Amazon MAB rain forest ecosystem pilot project at San Carlos de Rio Negro: Micrometeorological studies. Pa. ges 106-123 In: Transactions of the second international MAB-IUFRO workshop on tropical rainforest ecosystems research, 21-25 October, 1978, Jakarta, Indonesia (S. Adisoemarto and E. F. Brunig eds.). Special Report No. 2, Chair of World Forestry, Univ. of Hamburg, Hamburg F.R. Germany.

JORDAN, C.F.

1978 - Stem flow and nutrient transfer in a tropical rain forest. Oikos, 31, 257-263.

JoRdan, C.F.; Heuveldop, J.; PEeK, R.

1979 - Transpiration of a tropical rain forest: yearly rates for entire forest. Submitled to Tropical Ecology.

JORDAN, C.F. \& KLINE, J.R.

1977 - Transpiration of trees in a tropical rain forest. Journal of Applied Ecology, 14, 853860 .

JORDAN, C.F. \& UHL, C.

1978 - Biomass of a "tierra firme" forest of the Amazon Basin. Oecologia Plantarum, 13, 387-400.
KLINE, J.R.; REED, K.L.; WARING, R.H.; STEWART, M.L. 1976 - Field measurement of traıspiration in Douglas fir. Journal of Applied Ecology, 13, 272-283.

KLINGe, H.; Medina, E.; Herrrera, R.

1977 - Studies on the ecology of Amazon caatinga forest in southern Venezuela. Acta Cientifica Venezolana, 28, 270-276.

LIKENS, G.E. \& EATON, J.S.

1970 - A polyurethane stemflow collector for trees and shrubs. Ecology, 51, 938-939.

Marques, J.; Marden dos Santos, J.; Villa nova, N.A.;

SALATI, E.

1977 - Precipitable water and water vapor flux between Belem and Manaus. Acta Amazonica, 7 (3): 355-362.

MEdina, E.; HERRERA, R.; JoRdAN, C.; KLINGE, H.

1977 - The Amazon project of th Venezuelan Institute for Scientific Research. Nature and Resources, 13 (3). 4-7.

Villa nova, N.A.; Salati, E.; Matsui E.

1976 - Estimativa da evapotranspiração na Bacia Amazônica. Acta Amazonica, 6 (2): 215-228.

(Aceito para publicação em 21/11/80) 